\title{
The arable farmer as the assessor of within-field soil variation
}

\author{
S. Heijting $\cdot$ S. de Bruin $\cdot$ A. K. Bregt
}

Published online: 2 October 2010

(C) The Author(s) 2010. This article is published with open access at Springerlink.com

\begin{abstract}
Feasible, fast and reliable methods of mapping within-field variation are required for precision agriculture. Within precision agriculture research much emphasis has been put on technology, whereas the knowledge that farmers have and ways to explore it have received little attention. This research characterizes and examines the spatial knowledge arable farmers have of their fields and explores whether it is a suitable starting point to map the within-field variation of soil properties. A case study was performed in the Hoeksche Waard, the Netherlands, at four arable farms. A combination of semi-structured interviews and fieldwork was used to map spatially explicit knowledge of within-field variation. At each farm, a field was divided into internally homogeneous units as directed by the farmer, the soil of the units was sampled and the data were analysed statistically. The results show that the farmers have considerable spatial knowledge of their fields. Furthermore, they apply this knowledge intuitively during various field management activities such as fertilizer application, soil tillage and herbicide application. The sample data on soil organic matter content, clay content and fertility show that in general the farmers' knowledge formed a suitable starting point for mapping within-field variation in the soil. Therefore, it should also be considered as an important information source for highly automated precision agriculture systems.
\end{abstract}

Keywords Precision agriculture · Farmers' knowledge - Soil sampling - Management zone $\cdot$ Within-field variation

\section{Introduction}

Considerable progress has been made over the past few decades on the development and application of precision farming techniques. Various sensors are now available

\footnotetext{
S. Heijting $(\bowtie) \cdot$ S. de Bruin · A. K. Bregt

Centre for Geo Information, Wageningen University, P.O. Box 47,

6700 AA Wageningen, The Netherlands

e-mail: sanne.heijting@wur.nl
} 
commercially for monitoring within-field variation of variables such as biomass, yield and soil properties. However one sensor has remained under exploited: the farmer. Farmers' knowledge of their fields, including soil properties, is the result of years of intensive contact by the farmer with his land (Winklerprins 1999). Although it is often regarded as subjective and strongly dependent on context (Ingram 2008; Tsouvalis et al. 2000) in modern agriculture, farmers' knowledge will be a fusion of both experience and more standard scientific knowledge that has been assimilated by farming in highly technical arable systems (Ingram 2008; Tsouvalis et al. 2000). Within precision agriculture research, the view of the farmer on within-field spatial variation has been evaluated mainly in relation to yield maps or aerial images (Fleming et al. 2000; Hornung et al. 2006; Oliver et al. 2010; Seelan et al. 2003; Tsouvalis et al. 2000). With increasing possibilities of onfarm automation this form of knowledge can potentially be incorporated into so called expert systems (McKinion and Lemmon 1985; Papageorgiou et al. 2009), and as such further facilitates precision farming practices. Little is known about what the spatial knowledge of farmers encompasses, when it is perceived and whether they take it into account for field management.

Precision farming often requires information about within-field variation of, for example, soil attributes. Sampling on a grid for geostatistical interpolation requires an intensive, and thus costly, soil sampling scheme. The number of soil samples needed to determine within-field variation can be reduced by using ancillary variables such as apparent electrical conductivity $\left(\mathrm{EC}_{\mathrm{a}}\right)$ (Vitharana et al. 2006) and electromagnetic induction (EMI) (Taylor et al. 2003). Stratification of the field into management zones is another way to increase sampling efficiency (Simbahan and Dobermann 2006). Doerge (1999) defined a management zone as "a sub-region of a field that expresses a relatively homogeneous combination of yield limiting factors for which a single rate of a specific crop input is appropriate." Management zones can be established by classifying yield and soil data according to a given set of rules using techniques such as cluster analysis, for example (Fraisse et al. 2001; Shaner et al. 2008).

Identification of management zones can also be done by manual delineation following the method of Fleming et al. (2000) in which the farmer would integrate the following spatial layers: grey toned aerial image of the bare field, the viewpoint of the farmer on the field's topography and the farmer's knowledge of the field's past performance. Such farmer-defined management zones were found to reflect within-field differences in yield potential (Fleming et al. 2000; Hornung et al. 2006) and to represent underlying differences in soil characteristics (Fleming et al. 2000) such as texture, structure and soil organic-C (Mzuku et al. 2005). Classified images of aerial photographs that were taken during the growing season showed both a quantitative and qualitative resemblance to yield data at specific moments after planting (Vellidis et al. 2004). Management zones based on farmers' experience resulted in even more accurate zones to predict grain yield potential (Hornung et al. 2006).

In the present study we explore the spatial knowledge that farmers have and how it can be made explicit and used in site specific management. Furthermore, we study how it is derived and to what extent farmers currently apply this knowledge. Farmers' spatial knowledge of their fields was examined in depth using a combination of semi-structured interviews and field visits to map within-field variation. To assess the value of this knowledge for assessing within-field differences of the soil, information provided by the farmer on the within-field variation of soil attributes was compared with data from soil analysis. 


\section{Materials and methods}

Study area

The study was performed in the Hoeksche Waard, an island in the southwest of the Netherlands consisting of around 60 polders which were established from the late Middle Ages to the twentieth century. The island is mainly used at present for agricultural production and is known for its high yields. The landscape is characterized by its openness, dykes and creeks, and the region was granted the status of National Landscape in 2005 to preserve these features. According to the FAO World Reference Base for Soil Resources (2006) the soil can be classified mainly as calcaric fluvisols. According to the Dutch soil classification system the soil is identified as marine 'polder vague' soils comprising calcareous sandy loam to clay soils (de Bakker et al. 1989).

Farms and farmers

An overview of the four selected arable farms is provided in Table 1. Farmers (all male) were chosen based on age, farming type (conventional or organic (farm M)) and the location of their farm as all farms are on a different polder of the Hoeksche Waard. The four farms vary in size and crop rotation, age and experience of the farmers.

\section{Interviews}

Semi-structured interviews were held with each of the four farmers separately. The first part of the interview consisted of general questions about the farmer and his farm, and included topics such as (co-)ownership of farm, involvement in farm practices, years of experience, area and crop rotation. Questions on their interest in and use of GPS-related technology were also included. Knowledge of the farmer about the spatial variability of his farmland in general was explored in the second part of the interview. Possible features,

Table 1 Information on farms and farmers interviewed

\begin{tabular}{|c|c|c|c|c|}
\hline $\begin{array}{l}\text { Farm } \\
\text { code }\end{array}$ & $\begin{array}{l}\text { Size } \\
\text { (ha) }\end{array}$ & Crops grown & $\begin{array}{l}\text { Age of } \\
\text { farmer interviewed }\end{array}$ & Specific information \\
\hline Farm K & 175 & $\begin{array}{l}\text { Potatoes, onions, brussels } \\
\text { sprouts, poppy seeds, } \\
\text { cereals, sugar beet }\end{array}$ & 60 & $\begin{array}{l}\text { Farm owned by three brothers. } \\
\text { Involved in various innovation } \\
\text { projects }\end{array}$ \\
\hline Farm L & 50 & $\begin{array}{l}\text { Potatoes, sugar beet, } \\
\text { cereals, peas, silage } \\
\text { maize, onions }\end{array}$ & 40 & $\begin{array}{l}\text { Involved in projects on } \\
\text { biodiversity, soil structure and } \\
\text { precision agriculture }\end{array}$ \\
\hline Farm M & 20 & $\begin{array}{l}\text { Grass/clover mixture, red } \\
\text { cabbage, white } \\
\text { cabbage, celeriac, } \\
\text { celery, leek, zucchini }\end{array}$ & 31 & $\begin{array}{l}\text { Farm owned by two brothers. } \\
\text { Biological vegetable farmer, } \\
\text { owner of web shop of } \\
\text { biological products, involved in } \\
\text { various research projects }\end{array}$ \\
\hline Farm N & 40 & $\begin{array}{l}\text { Sugar beet, potatoes, } \\
\text { cereals, onions, poppy } \\
\text { seeds }\end{array}$ & 54 & $\begin{array}{l}\text { Owner of crane rental company, } \\
\text { teacher on technical school, } \\
\text { previously involved in project } \\
\text { on integrated farming }\end{array}$ \\
\hline
\end{tabular}


such as soil properties, yield, pests, weeds, that varied between and within-fields were discussed. In the third and most extensive part of the interview, the farmer was asked to specify further the within-field spatial variation of one specific field of his choice and to draw an accompanying map. Topics of discussion were scale of variation, field history, important periods of knowledge acquisition of within-field variability and sources of knowledge. The past and current treatment of the different management zones was reviewed. Next, a field visit was made during which spatially varying factors were investigated further. The boundaries of the different management zones, as marked by the farmer, were geo-referenced. Field geometry was measured by a local agricultural contractor with a GPS receiver providing centimetre level accuracy with a RTK (real time kinematic) correction signal. For detailed description of this method see de Bruin et al. (2009). The budget allowed two fields of the last farmer interviewed to be sampled.

To avoid boundary effects (Fleming et al. 2000; Shaner et al. 2008), farmers in this study were asked to indicate what buffer they would like to use near zone boundaries. In addition, parts of the field that were not of interest to the farmer, such as headlands, could be left out of the sampling scheme on the indication of the farmer. Management zone boundaries and buffers were visualized using ArcGIS ${ }^{\circledR} 9$ (ESRI, Redlands, CA, USA) and shown to the farmers. After the farmer approved the zones delineated in the field, five random sampling sites were selected within each farmer-defined management zone using $\operatorname{ArcGIS}^{\circledR}$ 9. Five was chosen as a practical balance between budget constraints and to provide enough data for an ANOVA of the soil properties. The final schedule was presented to the farmer for acceptance before the sampling locations were located in the field using RTK GPS.

Soil sampling and analysis

To reduce the effects of small scale variation, the soil from 15 to 20 sub-samples was mixed. The sub-samples were taken with a farmland auger $(\varnothing 0.013 \mathrm{~m})$ to a depth of $0.25 \mathrm{~m}$ and within $0.5 \mathrm{~m}$ of each sampling location. Soil samples were air dried at $40^{\circ} \mathrm{C}$, crushed and sieved at $2 \mathrm{~mm}$, and plant debris and stones were removed. After the preliminarily treatment, the values of the following properties were determined: nitrogen total $\left(\mathrm{N}_{\text {tot }}\right.$; in $\left.\mathrm{mg} \mathrm{N} \mathrm{kg}^{-1}\right)$, organic-C (\%), phosphorus ( $\mathrm{mg} \mathrm{P} \mathrm{kg}^{-1}$ and as $\mathrm{mg} \mathrm{P}_{2} \mathrm{O}_{5} \mathrm{~kg}^{-1}$ ) and clay content $(\%<2 \mu \mathrm{m})$. Total nitrogen and organic-C were determined using near infrared (NIR) spectroscopy (Terhoeven-Urselmans et al. 2008). Soil organic matter (SOM, in \%) was calculated from organic-C by multiplying it by a factor two. Readily available phosphorous (P-PAE; in $\mathrm{mg} \mathrm{P} \mathrm{kg}^{-1}$ ) was determined by solution in $0.01 \mathrm{M} \mathrm{CaCl}_{2}$ and subsequent spectrophotometric detection of molybdate colouring at $880 \mathrm{~nm}$ (Houba et al. 1998, 2000). Plant available phosphorous ( $\mathrm{P}-\mathrm{AL}$; in $\mathrm{mg} \mathrm{P}_{2} \mathrm{O}_{5} \mathrm{~kg}^{-1}$ ) was determined by solution in $0.1 \mathrm{M}$ ammonium lactate and $0.4 \mathrm{M}$ acetic acid at pH 3.75 (Egner et al. 1960) and subsequent spectrophotometric detection of molybdate colouring at $880 \mathrm{~nm}$. Percentage clay $(<2 \mu \mathrm{m})$ was established according to the Dutch standard NEN 5753, which is based on settling velocity (ISO 11277 2009).

\section{Data visualisation and statistical analysis}

Contents of the interviews were analyzed and summarized. Information provided by the farmers on their fields and management zones was summarized in tables to make direct comparison possible with the results of the soil analyses. Means per zone for each soil property were compared statistically with a one-way ANOVA using fixed effects and with 
the zones as treatment factors using GenStat 12.1 (VSN International Ltd, 2009). For fields with three or more zones, comparisons between individual pairs were made using the Tukey multiple comparison test to compensate for an increase in Type I error because of the large number of pairwise comparisons. The probability value ( $F$ prob) corresponding to the variance ratio was calculated, and statistical differences between individual pairs of zones were evaluated at $p<0.001, p<0.01$ and $p<0.1$.

\section{Evaluation}

Both the quantitative outcome of the soil sampling and the results of the statistical analysis were evaluated with each farmer separately. The farmers were asked whether the results of the soil analysis accorded with their expectation, and if not what possible causes might be linked to this. Next, adaptation of the management zones was discussed based on the results of this research.

\section{Results}

\section{Summary of general findings of interviews}

All farmers stated that there was variation between fields of the farm and that fields differed with respect to the degree of within-field variation. Farmer L mentioned that within-field variation was larger than variation between his fields.

The farmers in this study aim for a uniform yield, although there is within-field spatial variation of the soil. It is important to note that none of the farmers interviewed currently uses GPS for automated site-specific management, but they all vary within-field management manually while driving across the field. Farm $\mathrm{K}$ is the only farm in this study that uses GPS for automated navigation. When asked about his experience with the GPS, farmer K stated that working with GPS greatly increased his spatial awareness.

Farmers in this study were actively involved in most of the field operations on their farm, and they ploughed their selected field themselves. Ploughing and other soil tillage activities were regarded by all farmers as the most important for sensing within-field variation in texture, structure, soil organic matter content and variation in thickness of the topsoil layer. Crop growth at the start of the season, yield and behaviour of the soil under various weather conditions (rainfall, drought) also reveal important features of a field.

Detail on the selected fields for further study are given in Table 2. Both farmers $\mathrm{K}$ and $\mathrm{N}$ have worked their field for over 35 years, whereas the other two farmers acquired their land in 2000 (farmer L) and 2001 (farmer M), respectively. Sources of the spatial knowledge of the four participating farmers varied from a single aerial photograph to remotely sensed imagery and Google Earth ${ }^{\circledR}$. Four of the five fields in the study are adjacent to a dyke which gives the farmer the unique opportunity to inspect his field from a higher position.

The number of zones per field varied between 2 and 6 (Tables 3, 4, 5, 6; Figs. 1, 3, 5, 6). All farmers perceived smaller scale variation in their fields, but they appeared to use a relevance filter to sieve information for the mental map and the subsequent spatially variable management. In this respect, farmer $\mathrm{K}$ mentioned that given the current level of technology and economical feasibility, the most important level of scale for farmers is a limited number of management zones. Soil texture and thickness of the topsoil layer are likely to vary with distance from the dyke because of sedimentation before the formation of 


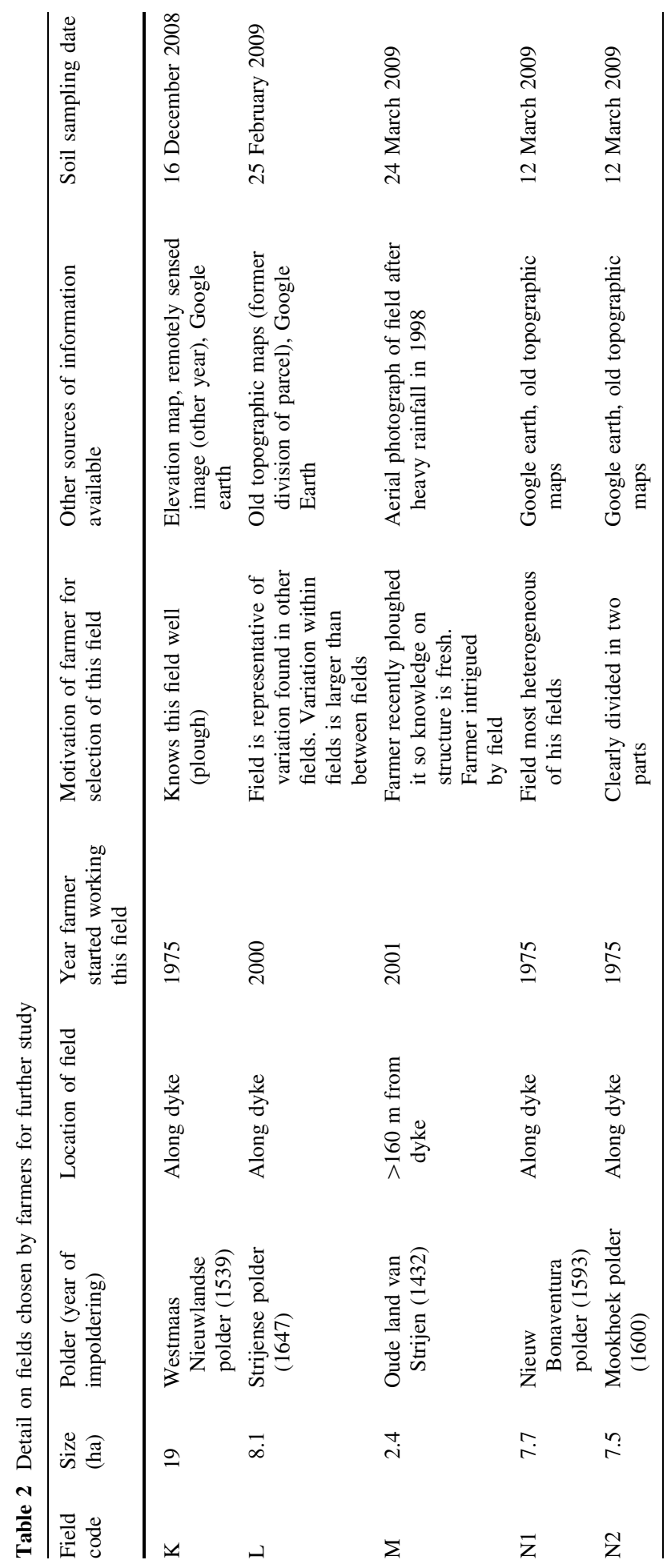


Table 3 Characteristics of farmer-defined management zones of field $\mathrm{K}$ according to farmer $\mathrm{K}$

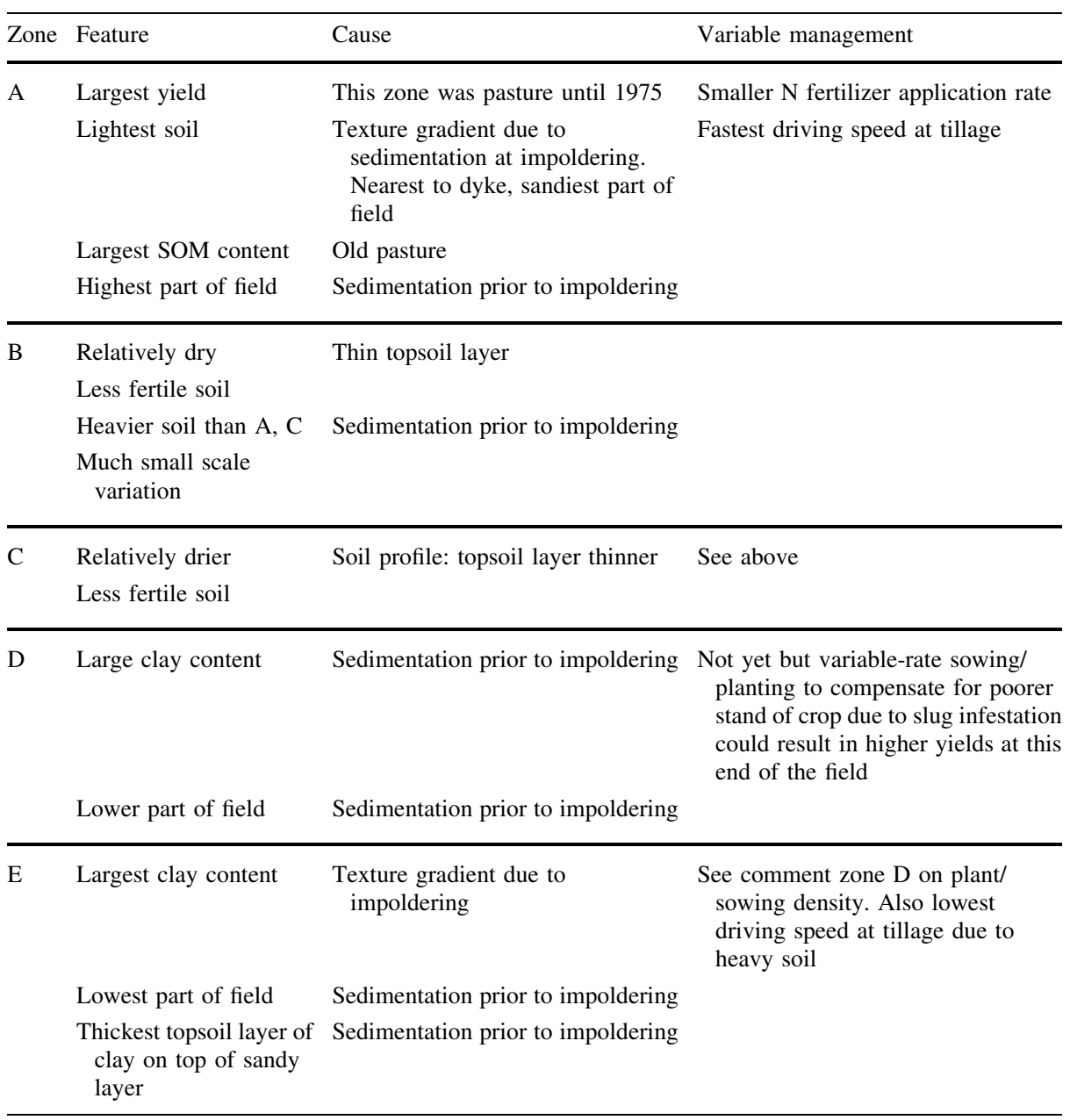

the polders. All farmers were aware of this and claimed to notice it during soil tillage, especially during ploughing. Another important reason for within-field variation as indicated by the farmers was land consolidation. Farms used to have at least one field of pasture for their cattle. During land consolidation since the 1960s such fields were merged with arable fields to form larger fields, but the larger SOM content in the area of former pasture is still present.

Details of the results per field are given below giving the farmer's view first, next the statistical analysis of the measured soil property values and finally an evaluation of the results.

\section{Field K}

Field K (Fig. 1; Table 3) is characterized by a former area of pasture (zone A) which is more fertile because of a larger SOM content than the other zones, and consequently needs 
Table 4 Characteristics of farmer-defined management zones of field L according to farmer L

\begin{tabular}{|c|c|c|c|}
\hline Zone & Feature & Cause & Variable management \\
\hline \multirow[t]{6}{*}{ A } & Heaviest soil & $\begin{array}{l}\text { Sedimentation prior to } \\
\text { impoldering }\end{array}$ & $\begin{array}{l}\text { Twice rotary harrowed (seed } \\
\text { bed preparation) in order to } \\
\text { remove clumps from soil } \\
\text { and get better stand of crop }\end{array}$ \\
\hline & Highest part of field & $\begin{array}{l}\text { Sedimentation prior to } \\
\text { impoldering }\end{array}$ & \\
\hline & Thickest furrow & $\begin{array}{l}\text { Sedimentation prior to } \\
\text { impoldering }\end{array}$ & \\
\hline & $\begin{array}{l}\text { Darker soil colour than } \\
\text { zone B \& C }\end{array}$ & & \\
\hline & Probably largest $\%$ SOM & & \\
\hline & Lower weed density & & \\
\hline \multirow[t]{2}{*}{$\mathrm{B}$} & Lowest part of field & $\begin{array}{l}\text { Sedimentation prior to } \\
\text { impoldering }\end{array}$ & $\begin{array}{l}\text { More herbicide used than on } \\
\text { zone A }\end{array}$ \\
\hline & $\begin{array}{l}\text { Higher weed density than } \\
\text { zone A }\end{array}$ & & \\
\hline \multirow[t]{4}{*}{$\mathrm{C}$} & Lightest soil & $\begin{array}{l}\text { Sedimentation prior to } \\
\text { impoldering }\end{array}$ & $\begin{array}{l}\text { More herbicide used than on } \\
\text { zone A }\end{array}$ \\
\hline & Thinnest furrow & & More $\mathrm{P}$ administered \\
\hline & Most sensitive to drought & & \\
\hline & $\begin{array}{l}\text { Higher weed density than } \\
\text { zone A }\end{array}$ & & \\
\hline $\begin{array}{l}\text { Former } \\
\text { ditches }\end{array}$ & Lighter colour & $\begin{array}{l}\text { Filled with soil from } \\
\text { elsewhere }\end{array}$ & \\
\hline
\end{tabular}

less nitrogen. Farmer K referred to this as 'old power' of the soil. Another important feature of this field according to the farmer is an overall increase in clay content with distance from the nearest dyke. The exception to this is zone B where clay content is greater than in zone $\mathrm{C}$. The texture gradient and variation in SOM were perceived during tillage, especially ploughing. In addition, thickness of the topsoil layer varies across the field with a thinner topsoil layer in zones B and C. The farmer stated that in zone E, larger yields could be expected if variable-rate sowing or planting were applied. The boundaries between zones $\mathrm{A}$ and $\mathrm{B}$, and $\mathrm{B}$ and $\mathrm{C}$ are former field boundaries. Part of zone $\mathrm{C}$ was omitted from soil sampling as it had been filled with soil from elsewhere in the past.

The results of the statistical analysis of the means per zone with ANOVA (Table 7) are consistent with the characterization of the zones by the farmer. Clay content of zone $\mathrm{E}$ $(27.2 \%)$ is significantly larger than that of the all other zones $(18.8-22.0 \% ; p<0.001)$. The clay content of zones A $(18.8 \%)$ and C $(19.6 \%)$ is significantly different from zones D, $\mathrm{B}$ and $\mathrm{E}(21.8-27.2 \% ; p<0.1)$. Zone $\mathrm{A}$, the former pasture, contains more $\mathrm{N}_{\text {tot }}$ (1946 mg N kg $\mathrm{mg}^{-1}$ ) and SOM (3.68\%) than all other zones $\left(1062-1476 \mathrm{mg} \mathrm{N} \mathrm{kg}^{-1}\right.$ and $2.04-2.72 \%$, respectively; $p<0.001$ ). Zone $\mathrm{E}$ has the second largest $\mathrm{N}_{\text {tot }}$ content $\left(1476 \mathrm{mg} \mathrm{N} \mathrm{kg}{ }^{-1}\right)$ of the field which is more than that of zone $\mathrm{C}\left(1062 \mathrm{mg} \mathrm{N} \mathrm{kg}{ }^{-1}\right.$; $p<0.001)$, D (1136 mg N kg$\left.{ }^{-1} ; p<0.1\right)$ and $\mathrm{B}\left(1202 \mathrm{mg} \mathrm{N} \mathrm{kg}^{-1} ; p<0.1\right)$. It also has the second largest SOM content $(2.72 \%)$, which is significantly larger $(p<0.01)$ than that 
Table 5 Characteristics of farmer-defined management zones of field $\mathrm{M}$ according to farmer $\mathrm{M}$

\begin{tabular}{llll}
\hline Zone & Feature & Cause & $\begin{array}{c}\text { Variable } \\
\text { management }\end{array}$ \\
\hline A & $\begin{array}{l}\text { Medium height } \\
\text { Medium yield }\end{array}$ & Old creek ridge & Levelling \\
& Medium pests and diseases & & \\
& Small SOM content & & \\
\hline
\end{tabular}

B Lower part of field

Levelling

Smallest yield

Water does not drain well after heavy rain

Impermeable layer underneath furrow. Old creek

Darker colour

Large SOM content

If heavy rain, cabbages start rotting

High density Stachys palustris L.

C Highest part of field with zone F $\quad$ Old creek ridge

Original furrow still intact

Largest yield, best part of field

Mostly perennials weeds such as Mentha arvensis L., Sonchus arvensis L., Stachys pallustris L.

D Lower part of field

Levelling

Smallest yield

Large SOM content

Water does not drain well after heavy rain

Impermeable layer underneath furrow. Old creek

E Medium height

Levelling

Medium yield

Low weed density

Low SOM content

$\mathrm{F} \quad$ Zone $\mathrm{F}$ and $\mathrm{C}$ highest part of field

Levelling

More snails and slugs

Near field edge with trees

Looser soil, darker colour

Darker colour possibly caused by largest SOM content

High density Galinsoga parviflora Cav.

of zones C (2.04\%) and D (2.12\%). Zone A has the largest P-PAE (2.22 $\left.\mathrm{mg} \mathrm{P} \mathrm{kg}^{-1}\right)$; the latter differs significantly from that of zones $\mathrm{C}\left(0.8 \mathrm{mg} \mathrm{P} \mathrm{kg}{ }^{-1} ; p<0.001\right), \mathrm{D}(0.9 \mathrm{mg} \mathrm{P}$ $\left.\mathrm{kg}^{-1} ; p<0.01\right)$, E (1.12 mg P kg$\left.{ }^{-1} ; p<0.01\right)$ and $\mathrm{B}\left(1.28 \mathrm{mg} \mathrm{P} \mathrm{kg}^{-1} ; p<0.1\right)$. Zone A also has the largest $\mathrm{P}-\mathrm{AL}$ content $\left(662 \mathrm{mg} \mathrm{P}_{2} \mathrm{O}_{5} \mathrm{~kg}^{-1}\right)$ which differs significantly from that of the zone with smallest value, zone $\mathrm{C}\left(468 \mathrm{mg} \mathrm{P}_{2} \mathrm{O}_{5} \mathrm{~kg}^{-1}\right)$. Values for measurements at 
Table 6 Characteristics of farmer-defined management zones of field N1 and N2 according to farmer N

\begin{tabular}{lll}
\hline Field Zone Feature & Cause & $\begin{array}{l}\text { Variable } \\
\text { management }\end{array}$ \\
\hline
\end{tabular}

N1 A $\quad$ Lighter colour

Lighter texture than rest of field Sedimentation at impoldering
Highest density black-grass
$\quad$ (Alopecurus myosuroides Huds.)

\begin{tabular}{|c|c|c|c|c|}
\hline & $\mathrm{B}$ & $\begin{array}{l}\text { Largest SOM content } \\
\text { Largest yield }\end{array}$ & Old pasture & Lower $\mathrm{N}$ rate \\
\hline & \multirow[t]{2}{*}{$\mathrm{C}$} & Heaviest soil, darker colour & & $\begin{array}{l}\text { Slower driving } \\
\text { speed at tillage }\end{array}$ \\
\hline & & Higher density nematode & & \\
\hline \multirow[t]{3}{*}{$\mathrm{N} 2$} & A & Largest SOM content & $\begin{array}{l}\text { Former owner put deep litter } \\
\text { house manure on zone A }\end{array}$ & Lower $\mathrm{N}$ rate \\
\hline & & Larger yield than zone B & & \\
\hline & & $\begin{array}{l}\text { Highest density black-grass } \\
\text { (Alopecurus myosuroides Huds.) }\end{array}$ & & \\
\hline
\end{tabular}

B Smaller SOM content than zone A

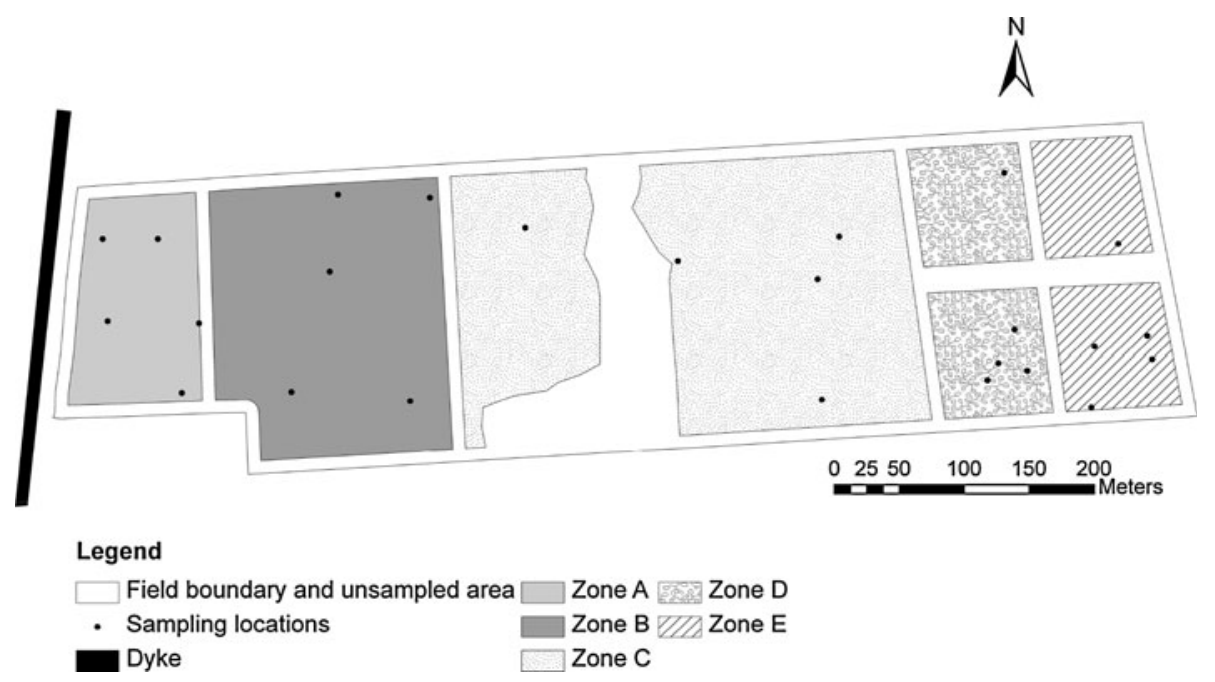

Fig. 1 Farmer-defined management zones and sampling locations of field $\mathrm{K}$

individual sampling locations are shown in Fig. 2 for clay \% (Fig. 2a), $\mathrm{N}_{\text {tot }}$ (Fig. 2b), SOM\% (Fig. 2c) and P-AL (Fig. 2d). The features of the different zones are expressed clearly by the individual values of the soil properties within a zone as variation within zones appears relatively small overall. The large clay content of zone $\mathrm{E}$ and large values of $\mathrm{SOM}$ and $\mathrm{N}_{\text {tot }}$ in zone A compared to other zones is evident in Fig. 2. 
Table 7 Results of one-way ANOVA

\begin{tabular}{|c|c|c|c|c|c|c|c|c|c|c|c|}
\hline \multirow[t]{2}{*}{ Field } & \multirow[t]{2}{*}{ Zone } & \multicolumn{2}{|l|}{ Clay (\%) } & \multicolumn{2}{|l|}{$\begin{array}{l}\mathrm{N}_{\text {tot }}(\mathrm{mg} \\
\left.\mathrm{N} \mathrm{kg}^{-1}\right)\end{array}$} & \multicolumn{2}{|l|}{ SOM (\%) } & \multicolumn{2}{|c|}{$\begin{array}{l}\text { P-AL } \\
\left(\mathrm{mg} \mathrm{P}_{2} \mathrm{O}_{5} \mathrm{~kg}^{-1}\right)\end{array}$} & \multicolumn{2}{|c|}{$\begin{array}{l}\text { P-PAE } \\
\left(\mathrm{mg} \mathrm{P} \mathrm{kg}^{-1}\right)\end{array}$} \\
\hline & & Mean & $\mathrm{SD}$ & Mean & SD & Mean & SD & Mean & SD & Mean & $\mathrm{SD}$ \\
\hline \multirow[t]{6}{*}{ K } & A & $18.8 \mathrm{a}$ & 1.5 & $1946 \mathrm{c}$ & 195 & $3.68 b$ & 0.3 & $662 b$ & 123.6 & $2.22 \mathrm{~b}$ & 0.7 \\
\hline & B & $22.0 \mathrm{a}$ & 1.2 & $1202 \mathrm{ab}$ & 55 & $2.36 \mathrm{a}$ & 0.2 & $534 \mathrm{ab}$ & 77.0 & $1.28 \mathrm{ab}$ & 0.5 \\
\hline & $\mathrm{C}$ & $19.6 \mathrm{a}$ & 1.5 & $1062 \mathrm{a}$ & 149 & $2.04 \mathrm{a}$ & 0.3 & $468 \mathrm{a}$ & 52.6 & $0.80 \mathrm{a}$ & 0.2 \\
\hline & $\mathrm{D}$ & $21.8 \mathrm{a}$ & 0.8 & $1136 a b$ & 58 & $2.12 \mathrm{a}$ & 0.2 & $564 \mathrm{ab}$ & 39.1 & $0.90 \mathrm{ab}$ & 0.4 \\
\hline & $\mathrm{E}$ & $27.2 b$ & 2.0 & $1476 \mathrm{~b}$ & 75 & $2.72 \mathrm{a}$ & 0.2 & $608 \mathrm{ab}$ & 48.7 & $1.12 \mathrm{ab}$ & 0.2 \\
\hline & & $p<0.001$ & & $p<0.001$ & & $p<0.001$ & & $p<0.01$ & & $p<0.001$ & \\
\hline \multirow[t]{5}{*}{$\mathrm{L}$} & A & $20.4 b$ & 2.6 & 1370 & 137 & $2.76 b$ & 0.3 & 448 & 99.1 & $0.58 \mathrm{a}$ & 0.2 \\
\hline & B & $16.2 \mathrm{ab}$ & 0.8 & 1036 & 111 & $2.12 \mathrm{a}$ & 0.2 & 402 & 44.4 & $0.52 \mathrm{a}$ & 0.1 \\
\hline & $\mathrm{C}$ & $14.4 \mathrm{a}$ & 1.1 & 1264 & 281 & $2.92 \mathrm{ab}$ & 0.7 & 504 & 65.0 & $0.96 b$ & 0.4 \\
\hline & Former ditch & $15.4 \mathrm{ab}$ & 1.8 & 1218 & 160 & $2.56 \mathrm{ab}$ & 0.3 & 444 & 55.0 & $0.76 \mathrm{ab}$ & 0.1 \\
\hline & & $p<0.001$ & & NS & & $p<0.1$ & & NS & & $p<0.1$ & \\
\hline \multirow[t]{7}{*}{ M } & A & $14.4 \mathrm{a}$ & 0.9 & $1014 \mathrm{ab}$ & 116 & $2.08 \mathrm{a}$ & 0.2 & $498 b$ & 51.2 & $1.14 \mathrm{~b}$ & 0.2 \\
\hline & B & $16.0 \mathrm{ab}$ & 0.7 & $1380 \mathrm{bc}$ & 128 & $3.16 \mathrm{~b}$ & 0.3 & $482 \mathrm{ab}$ & 44.4 & $0.92 \mathrm{ab}$ & 0.2 \\
\hline & $\mathrm{C}$ & $16.0 \mathrm{ab}$ & 1.7 & $1238 \mathrm{abc}$ & 122 & $2.60 \mathrm{ab}$ & 0.5 & $508 b$ & 691 & $1.16 \mathrm{~b}$ & 0.3 \\
\hline & $\mathrm{D}$ & $19.4 \mathrm{~b}$ & 1.5 & $1580 \mathrm{c}$ & 191 & $3.44 b$ & 0.4 & $568 \mathrm{~b}$ & 47.1 & $1.00 \mathrm{ab}$ & 0.2 \\
\hline & $\mathrm{E}$ & $19.0 \mathrm{~b}$ & 1.0 & $1374 \mathrm{bc}$ & 207 & $2.88 \mathrm{ab}$ & 0.3 & $500 \mathrm{~b}$ & 73.8 & $0.84 \mathrm{ab}$ & 0.3 \\
\hline & $\mathrm{F}$ & $16.4 \mathrm{ab}$ & 1.1 & $906 a$ & 120 & $2.00 \mathrm{a}$ & 0.3 & $304 a$ & 87.9 & $0.68 \mathrm{a}$ & 0.2 \\
\hline & & $p<0.001$ & & $p<0.001$ & & $p<0.001$ & & $p<0.001$ & & $p<0.1$ & \\
\hline \multirow[t]{4}{*}{ N1 } & A & $19.4 \mathrm{a}$ & 0.5 & $1226 a$ & 46 & $2.40 \mathrm{a}$ & 0.1 & $868 b$ & 65.3 & $1.70 \mathrm{~b}$ & 0.2 \\
\hline & B & $17.8 \mathrm{a}$ & 1.1 & $1908 b$ & 174 & $3.68 \mathrm{ab}$ & 0.2 & $588 \mathrm{a}$ & 78.6 & $1.66 \mathrm{~b}$ & 0.6 \\
\hline & $\mathrm{C}$ & $19.6 \mathrm{a}$ & 2.7 & $1572 b$ & 187 & $3.04 b$ & 0.4 & $544 a$ & 81.4 & $0.94 \mathrm{a}$ & 0.3 \\
\hline & & NS & & $p<0.001$ & & $p<0.001$ & & $p<0.001$ & & $p<0.1$ & \\
\hline \multirow[t]{3}{*}{$\mathrm{N} 2$} & A & $18.2 \mathrm{~b}$ & 0.8 & $1224 b$ & 80 & $2.76 b$ & 0.3 & $676 b$ & 52.2 & $2.18 \mathrm{~b}$ & 0.6 \\
\hline & B & $14.6 \mathrm{a}$ & 1.1 & $992 a$ & 130 & $2.32 \mathrm{a}$ & 0.3 & $484 \mathrm{a}$ & 28.8 & $0.88 \mathrm{a}$ & 0.3 \\
\hline & & $p<0.001$ & & $p<0.01$ & & $p<0.1$ & & $p<0.001$ & & $p<0.01$ & \\
\hline
\end{tabular}

Means per zone of soil properties and standard deviations (SD) are given. Lower case letters indicate the difference between management zones for the soil properties at the given significance level

The results of the statistical analysis of the soil data for this field is consistent with the information provided by the farmer, although the farmer expected larger quantitative differences. Nevertheless, he expected that the information gathered in the research could form a base for spatially variable agronomic advice. Farmer $\mathrm{K}$ claimed that much knowledge is currently lost as the new generation of farmers acts more like farm managers as they contract out farm activities and have less contact with their land than their colleagues used to. Ingram (2008) reported that according to some advisors, this trend has already resulted in a less intimate knowledge of the soil of farmers compared to some decades ago.

Farmer K appreciated that the results of the research confirmed his knowledge of the field. 

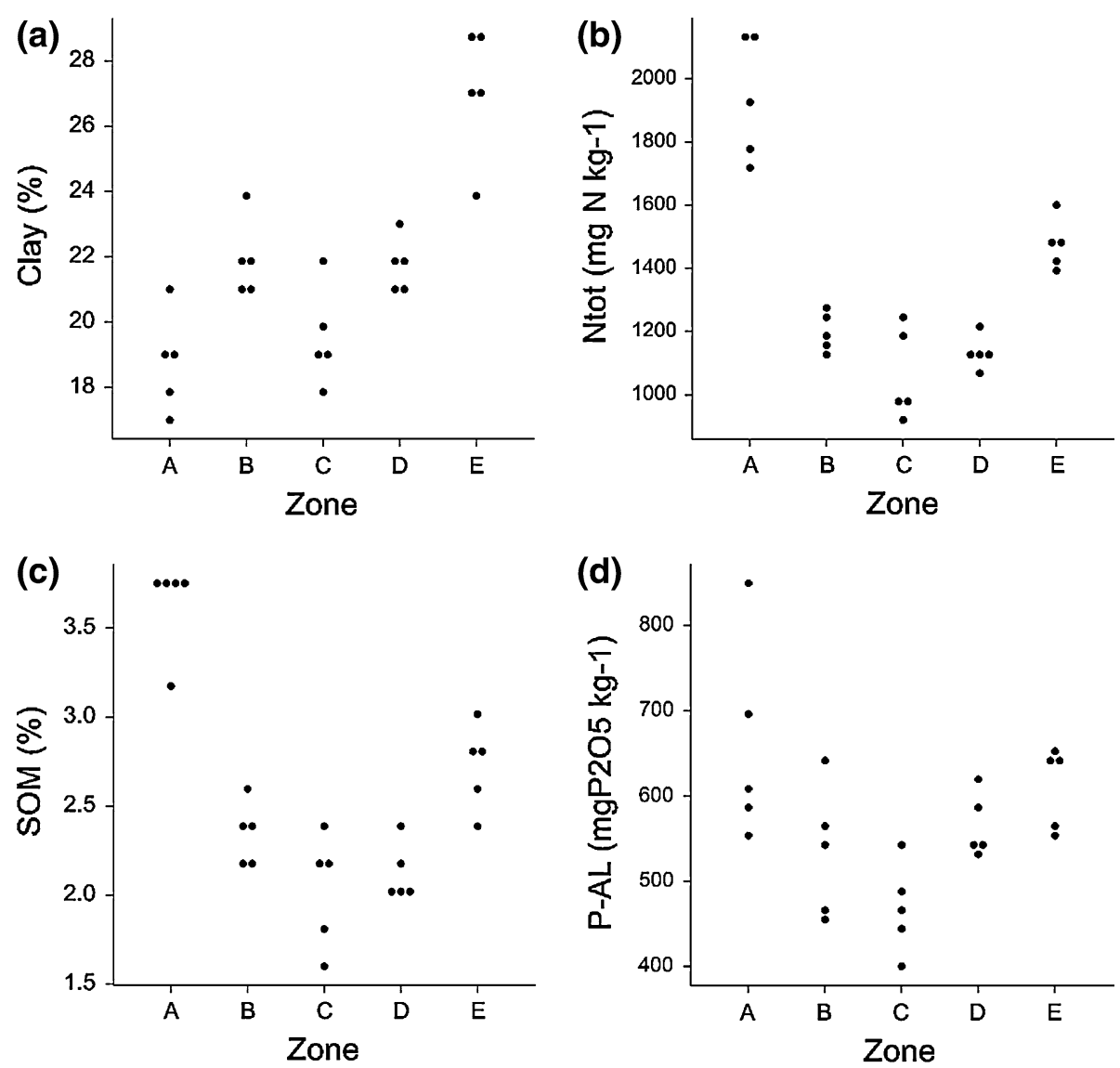

Fig. 2 Dot histograms of soil property values of field $\mathrm{K}$

Field L

Field L (Fig. 3; Table 4) is divided into four zones, including a former ditch. According to the farmer, there is a texture gradient with the largest clay content in zone A and smallest in zone $\mathrm{C}$. The boundary between the largest part of zones A to B is an old field boundary. The farmer adapts tillage and herbicide application to the within-field variation of soil texture and weed density, respectively, intuitively (Table 4) to obtain a uniform yield. For example, because of the larger clay content in zone A this area is rotary harrowed twice to remove large clumps of soil in the seedbed to obtain better establishment of the crop (Table 4).

The clay content of zone A $(20.4 \%)$ is significantly larger (Table 7) than that of zone B $(16.2 \% ; p<0.01)$, a former ditch $(15.4 \% ; p<0.01)$ and zone $\mathrm{C}(14.4 \% ; p<0.001)$, but the clay contents of zone $\mathrm{C}$ and $\mathrm{B}$ do not differ significantly. Zone $\mathrm{A}$ has the largest $\mathrm{N}_{\text {tot }}$ content $\left(1370 \mathrm{mg} \mathrm{N} \mathrm{kg}^{-1}\right)$, which is significantly larger $(p<0.1)$ than that of zone B $\left(1036 \mathrm{mg} \mathrm{N} \mathrm{kg}^{-1}\right)$. Distinct features of zones are reflected in the values of the actual

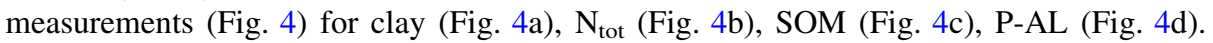
The SOM content of zone B $(2.12 \%)$ is significantly smaller (Table 7 ) than that of zone A 


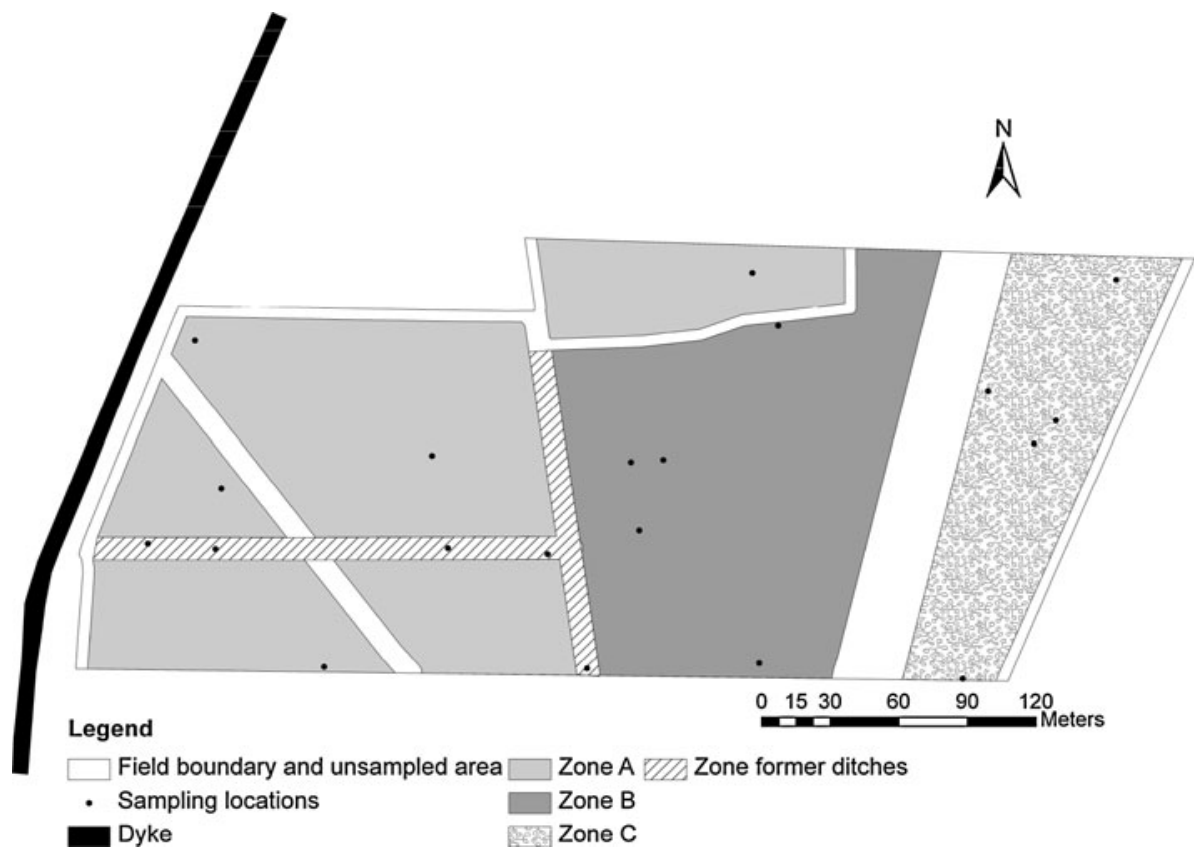

Fig. 3 Farmer-defined management zones and sampling locations of field L

$(2.76 \% ; p<0.1)$. Even though zone $\mathrm{C}$ has the largest SOM content $(2.92 \%)$, it does not differ significantly from zone $\mathrm{B}$ because of its large within-zone variation (Fig. 4c). One sampling point within zone $\mathrm{C}$ has large values for $\mathrm{N}_{\text {tot }}\left(1710 \mathrm{mg} \mathrm{N} \mathrm{kg}^{-1}\right.$; Fig. 4b) and SOM (4.0\%; Fig. 4c). It is the sampling point furthest north in zone C (Fig. 3). The farmer indicated that this was possibly due to temporary storage of chicken manure near to that area some years ago.

Farmer L expected larger differences between the values of the variables in the zones expressed by the data. He found it surprising that zone $\mathrm{C}$ has the largest $\mathrm{P}$ content. This could be a result of a larger dose of $\mathrm{P}$ fertilizer applied in the past (Table 4); on the basis of the soil analysis this no longer appears to be necessary.

\section{Field M}

Field M (Fig. 5; Table 5) is the smallest field in this study but is divided in the largest number of zones based on yield, performance after heavy rainfall, soil colour, weed species and level of slug infestation. At an early stage of the research, farmer $\mathrm{M}$ indicated that areas with poor yield in this field result from an impermeable layer in these parts of the field. The farmer also indicated that a creek ridge, formed by inversion of relief, was present in his field. In spring 2008 he had attempted to level the field by moving the topsoil. The soil in zone $\mathrm{C}$ only remained intact as it was not included in the levelling process. Mixing of the soil as a consequence of levelling complicated the assessment of soil texture and SOM content of the topsoil in all zones except for $\mathrm{C}$. The farmer expected SOM content to be largest in zones $\mathrm{F}$ and $\mathrm{B}$, and smallest in zones $\mathrm{A}$ and $\mathrm{E}$.

Mean clay content per zone (Table 7) is significantly less $(p<0.01)$ in zones A (14. 4\%), B (16.0\%) and C (16.0\%) than is that of zones $\mathrm{E}(19 \%)$ and $\mathrm{D}(19.4 \%) . \mathrm{N}_{\text {tot }}$ is on 

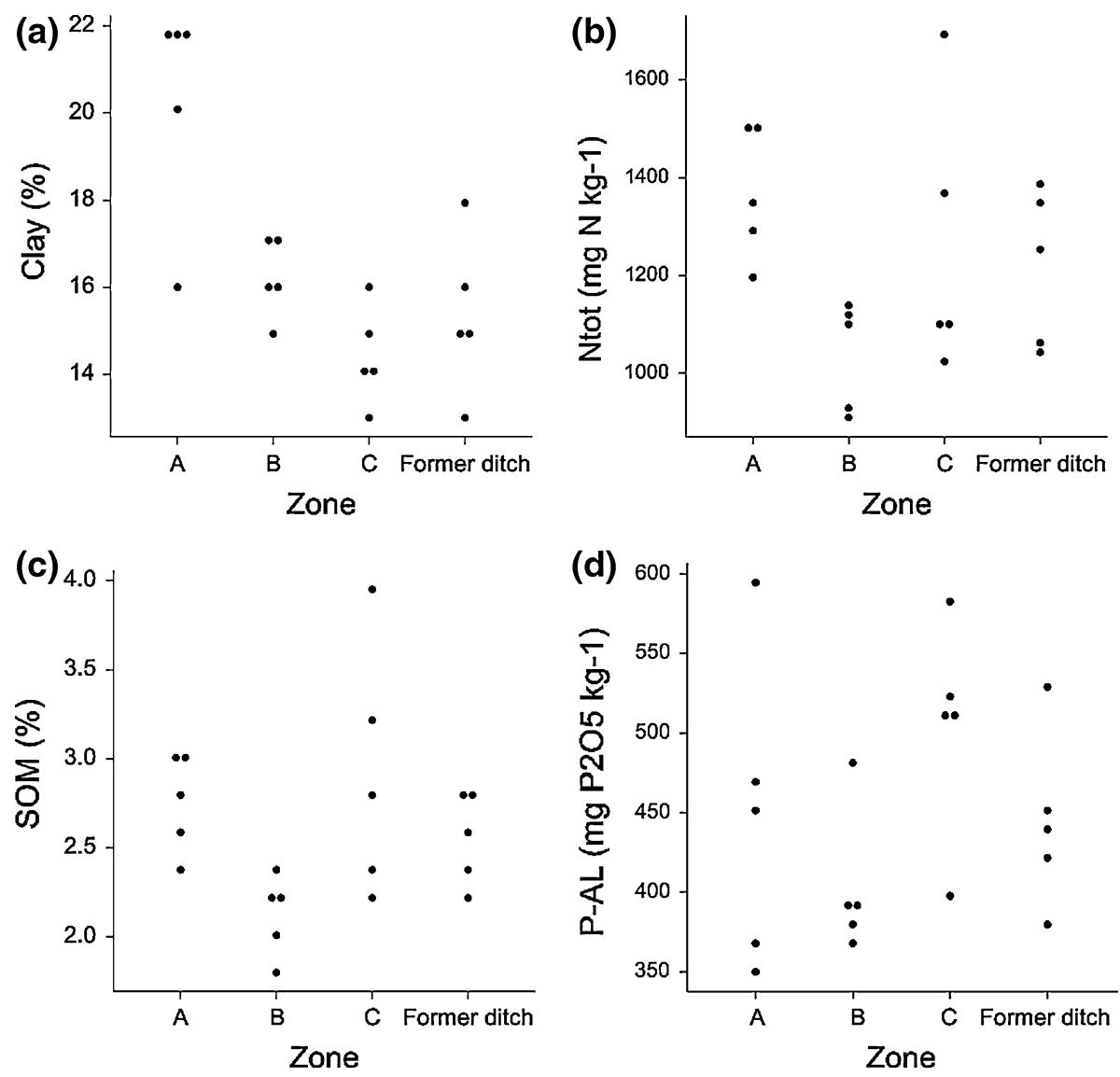

Fig. 4 Dot histograms of soil property values of field L

average significantly smaller $(p<0.01)$ in zones A $\left(1014 \mathrm{mg} \mathrm{N} \mathrm{kg}^{-1}\right)$ and F (906 $\mathrm{mg} \mathrm{N} \mathrm{kg}^{-1}$ ) than that in zones $\mathrm{B}\left(1380 \mathrm{mg} \mathrm{N} \mathrm{kg}^{-1}\right)$ and $\mathrm{D}\left(1580 \mathrm{mg} \mathrm{N} \mathrm{kg}^{-1}\right)$. The same trend is present for SOM content of the soil with that of zones A $(2.08 \%)$ and $\mathrm{F}$ $(2.0 \%)$ being significantly smaller $(p<0.001)$ than that of zones $\mathrm{B}(3.16 \%)$ and $\mathrm{D}$ (3.44\%). Zone $\mathrm{F}$ has the smallest $\mathrm{P}-\mathrm{AL}$ value $\left(304 \mathrm{mg}_{2} \mathrm{O}_{5} \mathrm{~kg}^{-1} ; p<0.01\right)$ of all zones (482-568 $\mathrm{mg} \mathrm{P}_{2} \mathrm{O}_{5} \mathrm{~kg}^{-1}$ ).

Additional measurements were made on field $\mathrm{M}$ to examine its subsoil characteristics as described by farmer $\mathrm{M}$ (see above). The subsoil was probed to a depth of $2.5 \mathrm{~m}$ at each of the 30 random sampling locations to determine the depth at which peat occurred, and in addition texture was estimated by hand texturing. Peat occurred at some depth at all sampling locations except for four in zone C. The soil in zones A, C, E and F has a decrease in clay content with increasing depth and there is an increase in clay content just above the depth at which peat occurs. Zone B has a profile in which the clay content increases with increasing depth and zone $\mathrm{D}$ has a more uniform soil profile.

The largest SOM content occurs in zones B and D where the farmer expected it to be large. Surprisingly SOM content is least in zone F, whereas the farmer expected it to be 


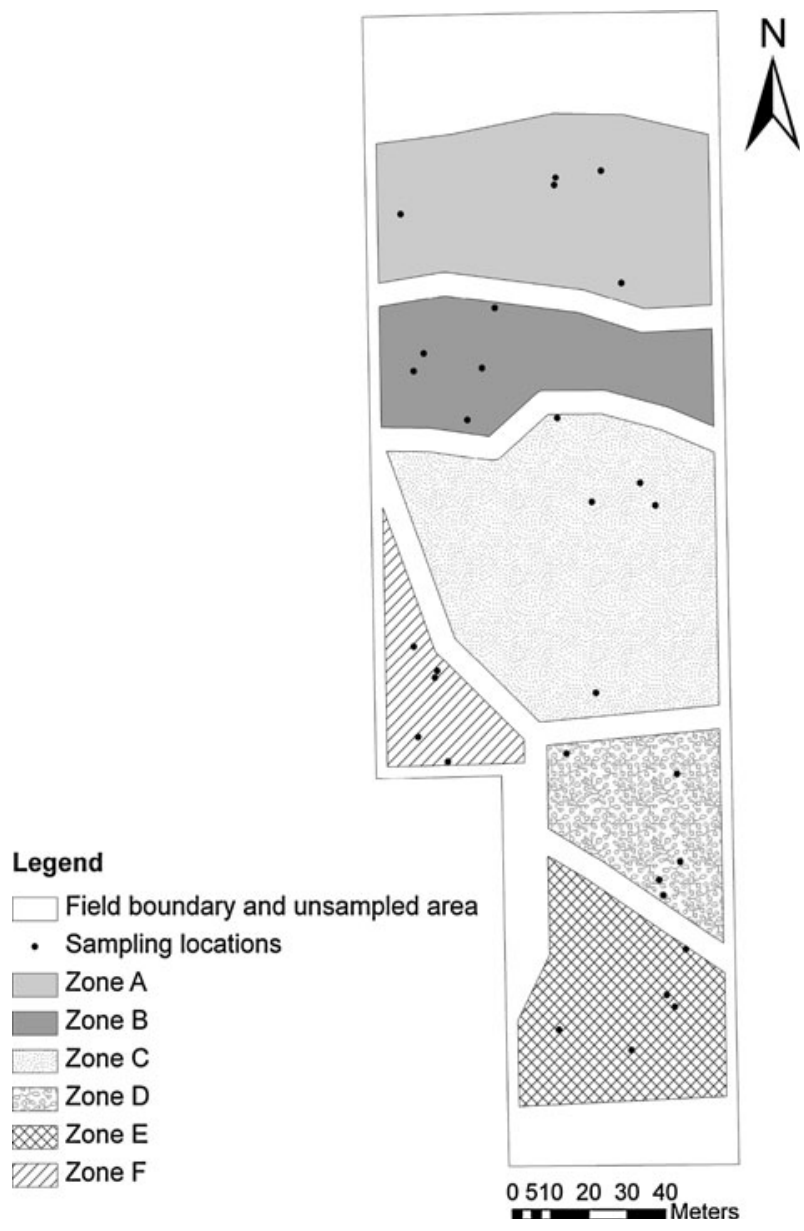

Fig. 5 Farmer-defined management zones and sampling locations of field $M$

possibly the largest. Overall, the troublesome zones B and D have good soil fertility, which emphasizes further that the farmer did not think soil fertility was the cause of the smaller yields in these zones. Underlying causes of poor crop performance are probably linked to differences in drainage caused by features of the soil profile as described above. The farmer indicated that he does not use variable-rate application of artificial fertilizers as this conflicts with the principles of organic farming.

\section{Fields N1 and N2}

According to the farmer, field N1 (Fig. 6; Table 6) has a texture gradient with increasing clay content with increasing distance from dyke, and an old pasture area (zone B) that has the largest yields. This old pasture receives less nitrogen fertilizer than the other zones (Table 6). Field N2 (Fig. 6; Table 6) is divided into two zones; zone A has the largest SOM content due to historical differences within the field (former pasture). 


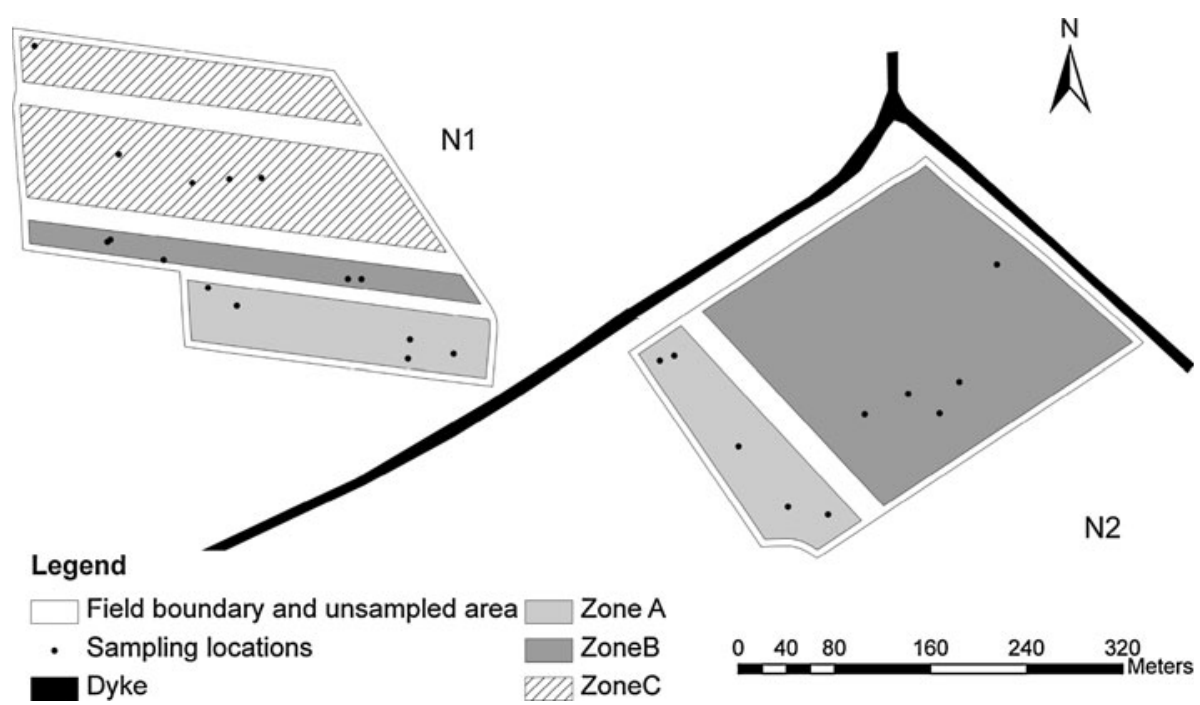

Fig. 6 Farmer-defined management zones and sampling locations of fields N1 and N2

Analysis of soil samples (Table 7) confirms that in field N1, zone B has on average the largest $\mathrm{N}_{\text {tot }}\left(1908 \mathrm{mg} \mathrm{N} \mathrm{kg}^{-1}\right)$ which is significantly different from zones A (1226 mg N kg$\left.{ }^{-1} ; p<0.01\right)$ and $\mathrm{C}\left(1572 \mathrm{mg} \mathrm{N} \mathrm{kg}^{-1} ; p<0.1\right)$. The SOM content of field $\mathrm{N} 1$ was largest in the area of old pasture, i.e. zone B $(3.68 \%)$ and differs significantly $(p<0.01)$ from zone $\mathrm{C}(3.04 \%)$, which in turn also differs significantly $(p<0.01)$ from that of zone A (2.4\%). The largest phosphate content of field N1 is in zone A (868 mg $\mathrm{P}_{2} \mathrm{O}_{5} \mathrm{~kg}^{-1}$ ) and it differs significantly from that in the other zones (544-588 mg $\left.\mathrm{P}_{2} \mathrm{O}_{5} \mathrm{~kg}^{-1} ; p<0.001\right)$. The clay content is on average largest in zone $\mathrm{C}$ $(19.6 \%)$ and smallest in zone B (17.8\%), but it does not differ significantly between the zones of field N1.

Zone A (former pasture) of field $\mathrm{N} 2$ has a larger clay content, $\mathrm{N}_{\text {tot }}, \mathrm{SOM}$, and both P-AL and P-PAE than zone B. Detail on values and significance are provided in Table 7.

Farmer $\mathrm{N}$ expected larger quantitative differences between the means per zone. The fact that clay content in field N1 did not show a significant increase with increasing distance from the dyke might have resulted from unsuitable choices for the sampling locations. Four of the five sampling sites were situated at about the same distance from the dyke and had a clay content of between 17 and $20 \%$, whereas the clay content of the sample furthest from dyke was $24 \%$.

\section{Discussion}

The farmers participating in this study take spatial variation into account when working their fields. They observe within-field variation of soil and other attributes such as yield, pests and weed infestations. Furthermore, they reported that they adjust field operations intuitively to the perceived within-field variation as far as they consider it practically feasible and economically relevant. Most important sources of information on within-field variation in our study were soil tillage, visual perception and historical knowledge on the 
field. Our findings on the importance of tillage for sensing the soil, are consistent with those of Ingram (2008) who reported that the practical knowledge arable farmers have on the spatial variation of soil properties in their fields was acquired during tillage operations in particular. Within-field variation of soil physical state can be mapped using a sensor that measures soil mechanical resistance (Sirjacobs et al. 2002). We propose that an initial step in mapping within-field variation of the soil can also be made during tillage by georeferencing transitions between areas that differ in workability as indicated by the farmer.

The description farmers provided of management zones in terms of soil properties corresponded largely with the results of the subsequent soil analysis. The division of fields into management zones in our study appeared to reflect important features of the landscape resulting from geomorphological processes and historical land use. It is likely that scientific and indigenous knowledge of the variation in soil in landscapes with distinct geomorphic units will be similar in general (Barrera-Bassols et al. 2009). The area of the present study (Hoeksche Waard) strongly reflects its history with its numerous polders and dykes that result in textural gradients. Differences between management zones in SOM content were strongly related to historic land use; farmers considered former pastures to be the most fertile zones. The soil analysis showed that these areas had the largest percentage SOM contents within the field. Grassland is known to increase SOM content, especially where the land has been under pasture for a long period of time (Pulleman et al. 2000).

The number of management zones per field in this study varied between 2 and 6 ; the smallest field had the largest number of zones. Most studies involving farmers' knowledge reported that three management zones only were delineated per field, representing areas of low, medium and high yield potential (Fleming et al. 2000; Hornung et al. 2006; Koch et al. 2004; Saleque et al. 2008). Those studies did not consider the size and nature of the field, which restricted the full potential knowledge of the farmers. When this restriction was not made in advance, Australian farmers indicated that there were more than three types of soil in a given field (Oliver et al. 2010; Wong et al. 2008).

The mental map the farmers have of their field is a result of the integration of information gathered throughout years of working the land. This image will often be selfevident to the farmer as it is part of their daily farming routine. Considering the strong spatial approach to farming the field and the insight that the farmer has on the within-field variation, it is important to map this knowledge so that it can be used and refined for further precision farming practices. Once a map had been made, this will increase spatial awareness and enhance adoption of precision farming techniques. For example, Larson et al. (2008) reported that farmers who make maps of their fields are 23.8 times more likely to adopt remote sensing practices. When comparing the view of the farmer with the statistical analysis, the significance of the result did not always express the relevance that within-field variation has to the farmer. When the farmers were confronted with the data, they noted that the data did not always express the differences as they observed them. Shaner et al. (2008) reported that if something differs little but is statistically significant, it is probably not of agronomic importance. This study has shown it may well be the other way round, with statistical testing being less sensitive than the farmer who has observed the agronomic importance over several years. Therefore, a possible advantage of asking a farmer to delineate a field into management zones could be that information gathered throughout years of practice will be integrated and level out the effects of specific conditions in a certain year. This is important as yield maps are known to vary strongly between years (Fraisse et al. 2001; Taylor et al. 2003).

The current study was limited in its set-up, but the effect of the origin of the landscape and land use history was reflected in the division into management zones in each of the 
selected fields. It will be valuable to test the approach in different types of landscape to determine whether a region-wide approach could possibly facilitate precision farming. In addition, by performing the method on a larger number of farms the universality of the intuitive practice of spatially variable management can be assessed.

\section{Conclusions}

In this study we examined the spatial knowledge of four farmers in the Hoeksche Waard about their fields using a combination of semi-structured interviews and fieldwork. The farmers showed that they have extensive spatial knowledge when asked to divide a field into management zones on the basis of their experience and knowledge. Within-zone characteristics as described by the farmers and the results of soil analyses generally coincided. Soil tillage appears to be an important time to perceive within-field differences in the soil texture and structure. Within-field variation of the measured soil properties reflected the historical land use and geomorphology of the landscape. The four farmers implicitly apply their spatial knowledge during field operations if they consider this to be technically and economically feasible.

The method used makes the knowledge, experience and practice of managing withinfield variation spatially explicit for the farmer, and such information could help farmers to optimize their management further. A second step would be to determine whether the experiences of farmers can be exchanged for crop improvement. For this purpose it is important to find out if farmers use similar characteristics for describing soil variables within regions having similar historical land use, geomorphology and general soil types. Experience and knowledge of farmers could be formalized in an expert system to deduct rules for adjusting farm operations to local circumstances.

Considering the added value of the spatial knowledge of farmers, a huge loss of knowledge may take place with the current trend towards increasing farm sizes managed by fewer farmers with an increase in outsourcing activities. Strikingly, within the framework of precision farming it is specifically detailed information on within-field variation that is needed. Therefore, spatial knowledge of farmers on within-field variation as shown in this study is regarded as an important information source, and also for highly automated precision agriculture systems.

Acknowledgments We gratefully thank Aad Klompe, Cees Schelling, Hans Rozendaal, Jan Verhoeven, Leo Klompe, Nico Barendregt, Huibert Breure and Philip Wenting for their kind cooperation during this research.

Open Access This article is distributed under the terms of the Creative Commons Attribution Noncommercial License which permits any noncommercial use, distribution, and reproduction in any medium, provided the original author(s) and source are credited.

\section{References}

Barrera-Bassols, N., Zinck, J. A., \& Van Ranst, E. (2009). Participatory soil survey: Experience in working with a Mesoamerican indigenous community. Soil Use and Management, 25, 43-56.

de Bakker, H., Schelling, J., Brus, D. J., \& van Wallenburg, C. (1989). Systeem van bodemclassificatie voor Nederland: de hogere niveaus. Wageningen: Pudoc.

de Bruin, S., Lerink, P., Klompe, A., van der Wal, T., \& Heijting, S. (2009). Spatial optimisation of cropped swaths and field margins using GIS. Computers and Electronics in Agriculture, 68, 185-190. 
Doerge, T. (1999). Management zone concepts. SSMG-2. http://ppi-far.org/ssmg.

Egner, H., Riehm, H., \& Domingo, W. R. (1960). Untersuchungen über die chemische Bodenanalyse als Grundlage für die Beürteilung des Nährstof-zustandes der böden. II. Chemische Extraktionsmethoden zur Phosphor- und Kaliumbestimmung. Lantbrukshoegsk. Annaler, 26, 199-215.

Fleming, K. L., Westfall, D. G., Wiens, D. W., \& Brodahl, M. C. (2000). Evaluating farmer defined management zone maps for variable rate fertilizer application. Precision Agriculture, 2, 201-215.

Fraisse, C. W., Sudduth, K. A., \& Kitchen, N. R. (2001). Delineation of site-specific management zones by unsupervised classification of topographic attributes and soil electrical conductivity. Transactions of the American Society of Agricultural Engineers, 44, 155-166.

Hornung, A., Khosla, R., Reich, R., Inman, D., \& Westfall, D. G. (2006). Comparison of site-specific management zones: Soil-color-based and yield-based. Agronomy Journal, 98, 407-415.

Houba, V. J. G., Novozamsky, I., \& Van Dijk, D. (1998). Certification of an air-dry soil for pH and extractable nutrients using one hundredth molar calcium chloride. Communications in Soil Science and Plant Analysis, 29, 1083-1090.

Houba, V. J. G., Temminghoff, E. J. M., Gaikhorst, G. A., \& Van Vark, W. (2000). Soil analysis procedures using $0.01 \mathrm{M}$ calcium chloride as extraction reagent. Communications in Soil Science and Plant Analysis, 31, 1299-1396.

Ingram, J. (2008). Are farmers in England equipped to meet the knowledge challenge of sustainable soil management? An analysis of farmer and advisor views. Journal of Environmental Management, 86, 214-228.

ISO 11277. (2009). Soil quality-Determination of particle size distribution in mineral soil materialMethod by sieving and sedimentation. Switzerland: International Organization for Standardization.

Koch, B., Khosla, R., Frasier, W. M., Westfall, D. G., \& Inman, D. (2004). Economic feasibility of variablerate nitrogen application utilizing site-specific management zones. Agronomy Journal, 96, 1572-1580.

Larson, J. A., Roberts, R. K., English, B. C., Larkin, S. L., Marra, M. C., Martin, S. W., et al. (2008). Factors affecting farmer adoption of remotely sensed imagery for precision management in cotton production. Precision Agriculture, 9, 195-208.

McKinion, J. M., \& Lemmon, H. E. (1985). Expert systems for agriculture. Computers and Electronics in Agriculture, 1, 31-40.

Mzuku, M., Khosla, R., Reich, R., Inman, D., Smith, F., \& MacDonald, L. (2005). Spatial variability of measured soil properties across site-specific management zones. Soil Science Society of America Journal, 69, 1572-1579.

Oliver, Y. M., Robertson, M., \& Wong, M. T. F. (2010). Integrating farmer knowledge, precision agriculture tools, and crop simulation modelling to evaluate management options for poor-performing patches in cropping fields. European Journal of Agronomy, 32, 40-50.

Papageorgiou, E. I., Markinos, A., \& Gemptos, T. (2009). Application of fuzzy cognitive maps for cotton yield management in precision farming. Expert Systems with Applications, 36, 12399-12413.

Pulleman, M. M., Bouma, J., Van Essen, E. A., \& Meijles, E. W. (2000). Soil organic matter content as a function of different land use history. Soil Science Society of America Journal, 64, 689-693.

Saleque, M. A., Uddin, M. K., Ferdous, A. K. M., \& Rashid, M. H. (2008). Use of farmers' empirical knowledge to delineate soil fertility-management zones and improved nutrient-management for lowland rice. Communications in Soil Science and Plant Analysis, 39, 25-45.

Seelan, S. K., Laguette, S., Casady, G. M., \& Seielstad, G. A. (2003). Remote sensing applications for precision agriculture: A learning community approach. Remote Sensing of Environment, 88, 157-169.

Shaner, D. L., Khosla, R., Brodahl, M. K., Buchleiter, G. W., \& Farahani, H. J. (2008). How well does zone sampling based on soil electrical conductivity maps represent soil variability? Agronomy Journal, 100, $1472-1480$.

Simbahan, G. C., \& Dobermann, A. (2006). Sampling optimization based on secondary information and its utilization in soil carbon mapping. Geoderma, 133, 345-362.

Sirjacobs, D., Hanquet, B., Lebeau, F., \& Destain, M. F. (2002). On-line soil mechanical resistance mapping and correlation with soil physical properties for precision agriculture. Soil and Tillage Research, 64, 231-242.

Taylor, J. C., Wood, G. A., Earl, R., \& Godwin, R. J. (2003). Soil factors and their influence on within-field crop variability, Part II: Spatial analysis and determination of management zones. Biosystems Engineering, 84, 441-453.

Terhoeven-Urselmans, T., Schmidt, H., Georg Joergensen, R., \& Ludwig, B. (2008). Usefulness of nearinfrared spectroscopy to determine biological and chemical soil properties: Importance of sample pretreatment. Soil Biology and Biochemistry, 40, 1178-1188.

Tsouvalis, J., Seymour, S., \& Watkins, C. (2000). Exploring knowledge-cultures: Precision farming, yield mapping, and the expert-farmer interface. Environment and Planning A, 32, 909-924. 
Vellidis, G., Tucker, M. A., Perry, C. D., Thomas, D. L., Wells, N., \& Kvien, C. K. (2004). Predicting cotton lint yield maps from aerial photographs. Precision Agriculture, 5, 547-564.

Vitharana, U. W. A., Van Meirvenne, M., Cockx, L., \& Bourgeois, J. (2006). Identifying potential management zones in a layered soil using several sources of ancillary information. Soil Use and Management, 22, 405-413.

Winklerprins, A. M. G. A. (1999). Local soil knowledge: A tool for sustainable land management. Society and Natural Resources, 12, 151-161.

Wong, M. T. F., Asseng, S., Robertson, M. J., \& Oliver, Y. (2008). Mapping subsoil acidity and shallow soil across a field with information from yield maps, geophysical sensing and the grower. Precision Agriculture, 9, 3-15.

World reference base for soil resources. (2006). World Soil Resources Reports No. 103. Rome: FAO. 